\title{
The effect of homogenization and sterilization on the stability and nutritional evaluation of Vietnamese purple rice milk supplemented with sesame, soybean and water caltrop
}

\author{
${ }^{1, *}$ Thuy, N.M., ${ }^{1,2}$ Banyavongsa, A. and ${ }^{1}$ Tai, N.V. \\ ${ }^{1}$ College of Agriculture, Can Tho University, Can Tho City, Vietnam \\ ${ }^{2}$ Faculty of Food Science, Savannakhet University, Laos
}

\begin{abstract}
Article history:
Received: 23 July 2020

Received in revised form: 22 August 2020

Accepted: 14 October 2020

Available Online: 29 October 2020
\end{abstract}

\section{Keywords:}

Purple rice,

Homogenization,

Sterilization,

Nutritional evaluation,

Stability

DOI:

https://doi.org/10.26656/fr.2017.4(6).379

\begin{abstract}
Lactose intolerance in human beings is the inability to digest significant amounts of lactose due to a shortage of the lactase enzyme. Rice milk is made as an alternative milk for people with limitation of milk consumption. The effect of (i) homogenization pressure (10-30 MPa) and time (5-20 mins); (ii) and sterilization conditions (3-11 mins at $\left.121.1^{\circ} \mathrm{C}\right)$ on the quality of purple rice milk were investigated. To understand the quality of rice milk, the Nutrition Facts was established and the percentage daily value was calculated. The study of homogenization with pressure and time showed that the lowest creaming index was achieved at pressure $20 \mathrm{MPa}$ and duration time of 10 to $15 \mathrm{mins}$, owing to the stable emulsions that were homogenized in the presence of additives. Sterilizing at $121.1^{\circ} \mathrm{C}$ for 7 mins could provide an acceptable microorganism compared to others. The results indicated that the percentage of calories from the macronutrients in this formula was within the AMDRs standard, with the percentage of calories ranges from 60.23, 15.26 and $24.5 \%$ of carbohydrate, protein and lipid, respectively. Furthermore, it was observed that the chemical components of the product were not significantly different during storage while the total microbial counts and lipid oxidation performed as peroxide value were lower than the maximum allowed limit after four months of storage at ambient temperature $\left(28 \pm 2^{\circ} \mathrm{C}\right)$.
\end{abstract}

\section{Introduction}

Milk and other dairy products are a major source of calcium and it is essential for the growth and repair of the bones. Lactose intolerance in human beings is the inability to digest significant amounts of lactose, the predominant sugar of milk. This inability results from a shortage of the enzyme, lactase, which is normally produced by the human cells that can then be absorbed into the bloodstream. Therefore, rice milk which is free from lactose maintains the nutritive value similar to dairy milk may be accepted by the consumers (Padma et al., 2018). Rice milk is considered the best hypoallergenic form of milk. Moreover, purple rice (Oryza sativa L.) is a special cereal which is cultivated in Vietnam and some other Asian countries. This rice contains high anthocyanin which is not only the common natural colour but also has potential applications such as the antioxidant component and many other health benefits (Hu et al., 2003). Recent studies on rice milk products have been carried out (Thuy et al., 2015; Banyavongsa et al., 2019), especially the study of Banyavongsa et al.
(2019) has formulated an appropriate formula between the purple rice, sesame, soybean and water caltrop milk. Soy milk, sesame milk and water caltrop milk, the water extract of soybean, sesame and water caltrop, offers a promising performance as a carrier of probiotics (Shimakawa et al., 2003). Furthermore, it is enriched in nutritive elements like proteins, unsaturated fatty acids, free amino acids and polypeptides, while containing only a small amount of saturated fatty acid and it lacks cholesterol or lactose (Yang and Li, 2010). Homogenization is a suitable process for the processing of rice milk. Previous research works have demonstrated that fat particle size, dispersion and temperature had significant effects on the stability of foods containing high-fat content such as milk, yoghurt and cheese (Shaker et al., 2000). The homogenization for reducing fat globule size is required before heat treatment to retain the emulsion stability. Besides, processing temperature also has a significant effect on the stability of rice milk. Furthermore, the previous research work demonstrated that more aggregates of fat globule were observed at higher heating temperatures (Simuang et al., 2004). 
From the literature described above, this research was aimed to investigate the effect of homogenizing pressure and time and sterilizing condition on the stability of rice milk. Moreover, the aim of this study also was to investigate the changes in the chemical composition during the storage and the establishment of Nutrition Facts of rice milk.

\section{Materials and methods}

\subsection{Materials}

Rice (ST Purple rice) (Figure 1) collected from Soc Trang province (Viet Nam), soybean (MTD 760 variety) supplied from Department of Genetics and Plant Breeding, College of Agriculture, Can Tho University, sesame and water caltrop were bought in the local market.

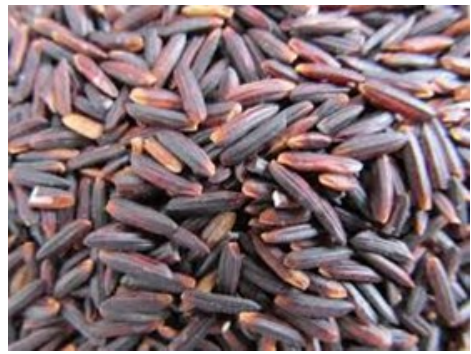

Figure 1. The purple rice

2.2 Preparation of rice milk supplemented with soybean, sesame and water caltrop milk

Before processing, purple rice was cleaned several times to remove dust, dirt and to reduce the chance of contamination, then blended into a puree. The ratio between rice and water is $1: 7$, and gelatinized at $85^{\circ} \mathrm{C}$ for $30 \mathrm{mins}$; the puree was liquefied by $0.149 \% \mathrm{v} / \mathrm{w} \alpha$ amylase at $80^{\circ} \mathrm{C}$ for 57 mins. The puree was saccharified by $0.143 \% \mathrm{v} / \mathrm{w}$ glucoamylase at $60^{\circ} \mathrm{C}$ for $40.94 \mathrm{mins}$. The suspension was filtered through 2 layer fabric (Banyavongsa et al., 2019). Soybean (MTD 760 variety) extracted by the simple traditional method of milk extraction (Ikya et al., 2013). Sesame milk prepared by using $12 \%(\mathrm{w} / \mathrm{v})$ initial concentration of seeds (Fitrotin et al., 2015). Water caltrop milk was prepared as described by Banyavongsa et al. (2019). After being obtained, all kinds of milk were mixed into a formulation. The ratio between rice milk, soybean milk, sesame milk and water caltrop milk were $70 \%, 10 \%, 8 \%$ and $12 \%$, respectively (Banyavongsa et al., 2019).

\subsection{Homogenization of purple rice milk}

The purple rice milk was kept overnight at $4^{\circ} \mathrm{C}$. Before all treatments, the milk was warmed to approximately $20^{\circ} \mathrm{C}$. The milk was homogenized at 10 , 15, 20, 25 and $30 \mathrm{MPa}$ for 5, 10, 15, 20 mins using a homogenizer (GJB-4-40, China) at an inlet temperature of $30 \pm 1^{\circ} \mathrm{C}$. The viscosity of purple rice milk measured using a dynamic viscometer (Brookfield DV-E, USA) The creaming index was analyzed as described by Bylund (2003).

\subsection{Sterilization of purple rice milk}

After selected homogenization conditions, purple rice milk was sterilized at $121.1^{\circ} \mathrm{C}$ for $3,5,7,9$ and 11 mins. The F-value was calculated as describes by Holdsworth (1985). Total viable counts were determined on Plate Count Agar medium (AOAC, 2005). The plates were incubated at $35^{\circ} \mathrm{C}$ for $48 \mathrm{hrs}$. The sterilized rice milk product was analyzed for the nutritional quality and stored at $28 \pm 2^{\circ} \mathrm{C}$ for 4 months.

\subsection{Physical and chemical analysis}

Moisture, protein, fat, crude fibre content and peroxide value were determined by AOAC (2005) methods. The total carbohydrate content was determined according to the method of McCseady (1971) and Dubois et al. (1956). The determination of calcium, sodium and potassium was carried out by flame photometry, then followed by the procedure of Arunkumar et al. (2015). The cholesterol content was determined according to the method of Dinh et al. (2008). Vitamin C was determined by Indophenol method (Zvaigzne et al., 2009). Total carotenoid content was determined according to the method of Parrish and Bauernfeind (1977).

\subsection{Calculation of total calories and percentage of the daily value $(\% D V)$}

Total calories of the milk were calculated by the formula as follows: total calories $(\mathrm{kcal})=$ fat $(\mathrm{g}) \times 9$ $(\mathrm{kcal} / \mathrm{g})+$ protein $(\mathrm{g}) \times 4(\mathrm{kcal} / \mathrm{g})+$ total carbohydrate (g) $x 4(\mathrm{kcal} / \mathrm{g})$. The $\% \mathrm{DV}$ for a nutrient is calculated by dividing the amount of a nutrient in a serving size by its daily value, then multiplying that number by 100 (Thomson and Manore, 2017).

\subsection{Statistical analysis}

Data analyses were carried out using STATGRAPHICS Centurion XV.I (U.S.A.). Values were expressed as percentage and mean \pm SD. The significance/non-significance of results was determined using one-way ANOVA.

\section{Results and discussion}

3.1 Effect of homogenization on the stability and viscosity of rice milk

The creaming index of the non-homogenized 
Table 1. The creaming index of purple rice milk at different pressure and time of homogenization

\begin{tabular}{cccccccc}
\hline Time (min) Pressure (MPa) & $\begin{array}{c}\text { Creaming index } \\
(\%)\end{array}$ & $\begin{array}{c}\text { Viscosity } \\
\left(\text { MPa. }^{-1}\right)\end{array}$ & Time (min) & $\begin{array}{c}\text { Pressure } \\
(\mathrm{MPa})\end{array}$ & $\begin{array}{c}\text { Creaming index } \\
(\%)\end{array}$ & $\begin{array}{c}\text { Viscosity } \\
\left(\mathrm{MPa} . \mathrm{s}^{-1}\right)\end{array}$ \\
\hline 5 & 10 & $7.30^{\mathrm{a}}$ & 1.82 & 15 & 10 & $4.68^{\mathrm{d}}$ & 1.86 \\
5 & 15 & $7.42^{\mathrm{a}}$ & 1.83 & 15 & 15 & $2.35^{\mathrm{fg}}$ & 1.86 \\
5 & 20 & $6.61^{\mathrm{b}}$ & 1.86 & 15 & 20 & $2.20^{\mathrm{gh}}$ & 1.88 \\
5 & 25 & $3.23^{\mathrm{e}}$ & 1.9 & 15 & 25 & $2.01^{\mathrm{hi}}$ & 1.92 \\
10 & 10 & $5.42^{\mathrm{c}}$ & 1.84 & 20 & 10 & $2.48^{\mathrm{f}}$ & 1.9 \\
10 & 15 & $4.87^{\mathrm{d}}$ & 1.86 & 20 & 15 & $2.15^{\mathrm{ghi}}$ & 1.91 \\
10 & 20 & $2.13^{\mathrm{ghi}}$ & 1.86 & 20 & 20 & $2.05^{\mathrm{hi}}$ & 1.92 \\
10 & 25 & $2.06^{\mathrm{hi}}$ & 1.92 & 20 & 25 & $1.94^{\mathrm{i}}$ & 1.96 \\
\hline
\end{tabular}

Values with different superscript letters within the column indicate a significant difference $(\mathrm{P}<0.05)$. The creaming index $(\%)$ and viscosity control purple rice milk were $48.153 \%$ and $1.8 \mathrm{MPa}^{-1}{ }^{-1}$, respectively

(control sample) and homogenized samples at different pressures and time were significantly different $(\mathrm{p}<0.05)$ (Table 1). The highest creaming index was found for the control sample (48.15\%). As the pressure and processing time increased, the creaming index decreased, indicating a high efficiency from the homogenization process. The homogenization with pressure $5,10,15$ and $20 \mathrm{MPa}$ in different times indicated that the creaming index decreasing remarkably from 7.29 to $3.23 \%, 5.42$ to $2.06 \%, 4.68$ to $2.01 \%$ and 2.48 to $1.94 \%$, respectively. Considered as the result of viscosity, the homogenized samples were slightly more viscous than the nonhomogenization rice milk because it is consistent with the presence of flocculated droplets. The better condition for homogenization as creaming stability was found in homogenized rice milk at the pressure above $20 \mathrm{MPa}$ and time above 10 minute, properly due to the higher viscosity in these samples and low in the creaming index. Non-homogenization rice milk is more prone to creaming than homogenized rice milk because of its larger globule size. Homogenization, through the application of pressure, is able to reduce the milk fat globule size and prevents fat separation from the milk (Sfakianakis and Tzia, 2014) due to pumping milk at high pressure through a valve. The process which breaks fat globules to smaller particles (about 3.5 to $1 \mu \mathrm{m}$ ) because the homogenization process does not sufficiency causes an increase in the separated area (Massoud et al., 2014). The better condition for homogenization as creaming stability was found in homogenized rice milk at the pressure above $20 \mathrm{MPa}$ and time above 10 minute, properly due to the higher viscosity in these samples and low in the creaming index. The effect of homogenization on the change of the rice milk in the physical properties results from an increase in milk fat dispersion degree and the subsequent absorption of milk protein on the interphase surface. The level of protein adsorbed on the surface of fat globules and their interactions with plasma proteins play an essential role in the stabilization of homogenized milk. Al-Hilphy et al. (2012) found that the creaming index was reduced with increasing time of homogenization with ultrasonic treatments at the power of 338 and $430 \mathrm{~W}$. Ultra-high pressure homogenization (UHPH) also effected on the physico-chemical characteristics of tiger nuts' milk (Codina-Torrella et al., 2017), the final product presented the highest colloidal stability after treatment, principally against creaming rate due to the reduction in particle size and the new particle interactions.

\subsection{Effect of sterilization of quality and the shelf-life of rice milk}

Steam sterilization is non-toxic, inexpensive, rapidly microbial sporadic and rapidly heat and penetrates fabrics (Gaillard et al., 2005). As far as the sterilization is concerned, the combination of temperature and time of the lethal effect on microorganism and the chemical substance present is influenced by sterilization. The sterilization was selected based on the basis of $F \geq F_{0}$. Depending on the $\mathrm{pH}$ value and target microorganisms, rice milk is standardized with $\mathrm{pH}>4.6$. So, the target microorganism for sterilization values is 3 (Weemaes, 1997). Thus, the results in Table 2 showed that the product could be sterilized at temperature $121^{\circ} \mathrm{C}$ for 5 and 7 mins (corresponding with the F-value were 4.8 and 6.84 , respectively). Sterilization condition $\left(121^{\circ} \mathrm{C}\right.$ for 7 mins) was adopted in this case due to the sensory characteristics of the product.

\begin{tabular}{ccc}
\multicolumn{3}{c}{ Table 2. Sterilization regimes (F-value) } \\
\hline Time $(\mathrm{min})$ & Temperature $\left({ }^{\circ} \mathrm{C}\right)$ & F-value \\
\hline 3 & 121 & 2.93 \\
5 & 121 & 4.8 \\
7 & 121 & 6.84 \\
9 & 121 & 8.79 \\
11 & 121 & 10.74 \\
\hline
\end{tabular}

3.3 The nutritional values, energy-yielding and energy balance

The proportion of energy provide from the main nutrients in purple rice milk was presented in Table 3 . 
Rice is always perceived as a rich carbohydrate source in diet and similarly, it is observed that rice milk contains more sugar than normal cow's milk. Rice milk is lactosefree making itself a perfect alternative for patients suffering from the lactose intolerance (Lomer et al., 2008). Acceptable Macronutrient Distribution Ranges for Adults (as a percentage of Calories) are as follows: protein: $10-35 \%$, fat: $20-35 \%$, carbohydrate: $45-65 \%$. A balance of the macronutrients can help ensure adequate intakes of micronutrients as well (Thompson and Manore, 2017). The percentage of calories from the macronutrients in this formula was within the AMDRs standard, ranging from $60.23,15.26$ and $24.5 \%$ of carbohydrate, protein and lipid, respectively. A diet which is balanced in the macronutrient distribution is recommended for the malnutrition and over intake because unbalanced nutrients profile causes an increased risk of problem health such as chronic disease, diabetes, cancer and various other health complications (Shannon and Rodriguez, 2014). The Nutrition Facts of the purple rice milk was established (Figure 2). As in the General Guide to Calories (based on a 2,000 calorie diet): 40 Calories is low, 100 Calories is moderate and 400 Calories or more is high. The calculation of energy in this product was moderated accounting for 159.98 calories. The percentage of the daily value (\%DV) shown in the Nutrition Facts label is the guide to the nutrients in one serving of food and met the energy requirement of alternative milk for people who have lactose allergy from cow's milk. The rice milk was free of lactose and cholesterol but it had the sweetness from starch and energy $\approx 96.36$ calories $(29.2 \mathrm{cals} / 100 \mathrm{~mL})$ for serving size. The calculated $\% \mathrm{DV}$ of vitamin $\mathrm{A}$ is $0.06 \%$, it means that the content of this component in the product is less $(\leq 5 \%)$. Some of the components are identified as the limit, such as fat, saturated fat, trans fat, cholesterol, or sodium. The calculated $\% \mathrm{DV}$ of sodium $(0.04 \%)$ (less than $5 \%)$. However, the $\% \mathrm{DV}$ of carbohydrate and fat were estimated at $8.03 \%$ and $6.7 \%$ (between 5 and 20\%), indicating a good nutritional product. The high amounts of these components $(\%$ DV $>20 \%$ ) may increase the risk of certain chronic diseases. Health experts recommend that we keep our intake of saturated fat, trans fat and cholesterol as low as possible as part of a nutritionally balanced diet. However, the product contained a moderate amount of fiber ( $\% \mathrm{DV}$ is $13.12 \%)$, calcium $(5.95 \%)$ and iron content $(17.27 \%)$. With the energy and nutritional value provided, this product is usually to be able to partly meet the energy requirements for healthy food. In addition, considering that the price of rice milk was lower than cow's milk, it is a good choice for people who are lactose intolerant or cow's milk allergic.
Table 3. Macronutrient content, yielding-energy and percentage of energy providing from $100 \mathrm{~mL}$ of purple rice milk

\begin{tabular}{cccc}
\hline Nutrients & $\begin{array}{c}\text { Content } \\
(\mathrm{g})\end{array}$ & $\begin{array}{c}\text { Energy-yielding } \\
\text { nutrients } \\
\text { (Calories) }\end{array}$ & $\begin{array}{c}\text { Percentage of } \\
\text { energy providing } \\
\text { from nutrients (\%) }\end{array}$ \\
\hline Carbohydrate & 7.3 & 29.2 & 60.23 \\
Protein & 1.85 & 7.4 & 15.26 \\
Lipid & 1.32 & 11.88 & 24.5 \\
\hline Total & & 48.48 & 100 \\
\hline
\end{tabular}

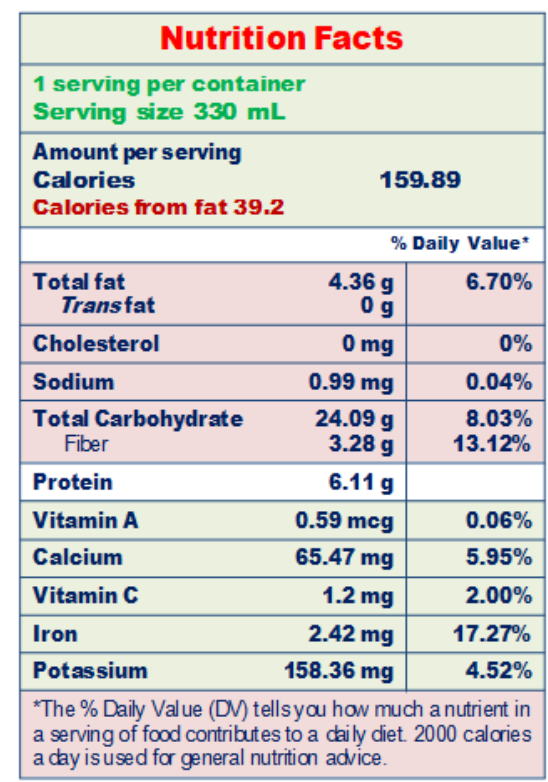

Figure 2. Nutrition facts of purple rice milk

\subsection{Microbiological analysis}

The microbiological analysis of rice milk during storage are given in Table 4, the absence of coliform bacteria was found while the number of total viable count (TVC) of the milk was detected in the $3^{\text {rd }}$ and $4^{\text {th }}$ month accounting for $1.5 \times 10^{2}$ and $1.8 \times 10^{2} \mathrm{CFU} / \mathrm{mL}$, respectively. These values were below the limit of acceptable counts for dairy milk. Jay (2008) suggested the anaerobic plate count of milk from healthy dairy products should be less than $10^{3} \mathrm{CFU} / \mathrm{mL}$. According to Onweluzo et al. (2009), the TVC in vegetable milk was less than the limit of acceptable level for milk products. It could be observed that the rice milk products could be stored at ambient temperature $\left(30 \pm 2^{\circ} \mathrm{C}\right)$ for 4 months.

Table 4. Microbiological analysis of rice milk during storage

\begin{tabular}{ccc}
\hline $\begin{array}{c}\text { Storage } \\
\text { (month) }\end{array}$ & $\begin{array}{c}\text { Total viable count } \\
(\mathrm{CFU} / \mathrm{mL})\end{array}$ & $\begin{array}{c}\text { Coliform } \\
(\mathrm{CFU} / \mathrm{mL})\end{array}$ \\
\hline 1 & $\mathrm{ND}$ & $\mathrm{ND}$ \\
2 & $\mathrm{ND}$ & $\mathrm{ND}$ \\
3 & $1.5 \times 10^{2}$ & $\mathrm{ND}$ \\
4 & $1.8 \times 10^{2}$ & $\mathrm{ND}$ \\
\hline
\end{tabular}

ND, not detected.

\subsection{Chemical analysis of purple rice milk during storage}

The results indicated that the chemical compositions of purple rice milk including protein, fat and 
carbohydrate contents were not significantly affected by the storage while anthocyanin of the product was a significant change during storage (Table 5). Brodziak et al. (2017) illustrated a significant effect of temperature and storage time on the content of fat, lactose and dry matter, while only storage time was unaffected the protein content. Omer and Eltinay (2009) reported that storage milk at room temperature were significant changes in $\mathrm{pH}$, acidity, lactose, total solid but insignificant changes in protein when storage for 42 days. The anthocyanin compound showed a gradual decrease from $2.04 \%$ to $1.21 \%$ in the fourth month of storage due to the anthocyanin being more sensitive to degradation and easily affected by several parameters. Sivamaruthi et al. (2016) reported about the degradation of this compound quickly (about 90\%) by sterilization like heat and sonication. In addition, light is an essential factor required for the biosynthesis of pigments, it stimulates the anthocyanin denaturation faster than oxygen due to the UV protective nature of anthocyanin (Furtado et al., 1993). Thus, storing the anthocyanin-rich food materials at room temperature that contacts directly to the light resulted in decreasing anthocyanin compounds.

\subsection{The peroxide value of sterilized milk}

Sterilized milk is designed to extend the shelf-life of milk that can be stored at ambient temperature for a long period. In this work after four months of storage, the peroxide value increased slightly from 0.148 to 0.198 $\mathrm{meq} / \mathrm{kg}$ fat. The rise in peroxide value indicated in Figure 3, peroxide values slightly increased due to the breakdown of fatty acids into oxidation products. Lipid oxidation is known to be increased by several factors including heat, light, radiation, moisture and storage (Savage et al., 2002). The sample had a lower peroxide value when compared to the standard in milk should be less than $0.6 \mathrm{meq} / \mathrm{kg}$ fat (Codex Alimentarius International Food Standards, 2011). The lower peroxide value indicated a longer period of storage. The results of this study agreement to Ajmal et al. (2018) assessed the non-effect of peroxide value on UHT milk during storage period at 30, 60 and 90 days. Similarly, Baladhiya et al. (2018) reported the peroxide value of in-container sterilization of halwa did not affect on sensory attributes of the product after 90 days of storage.

\section{Conclusion}

The sufficiency of homogenization as creaming stability was found in homogenized rice milk after homogenized at a pressure above $20 \mathrm{MPa}$ for 15 mins. Comparing among commercial sterilizing conditions of study, heating at $121.1^{\circ} \mathrm{C}$ for 7 mins provided the acceptable mixed purple rice milk. The percentage of calories from the macronutrients was within the AMDRs standard. The nutrition compositions of the rice milk indicated unchanged after four months of storage. In addition, the present study demonstrated that purple rice milk could be considered as suitable economical substitutes for cow's milk and an ideal nutritional supplement for lactose intolerant population. The future works can be applied at a larger scale in order to fully utilize the available materials in Vietnam and create a new healthy nutritious food product.

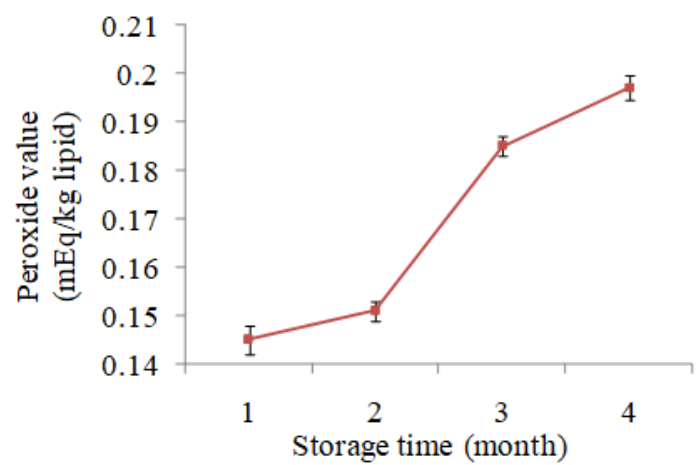

Figure 3. Effect of storage time on peroxide value of sterilized milk

\section{Conflict of interest}

The authors declare no conflict of interest.

\section{Acknowledgements}

We would like to express our gratitude to all those who gave us the possibility to complete this research. We would like to thank VLIR Network Vietnam Project for their support our study.

\section{References}

Ajmal, M., Nadeem, M., Imran, M. and Junaid, M. (2018). Lipid compositional changes and oxidation status of ultra-high temperature treated Milk. Lipids Health Disease, 17(1), 17-227.

Al-Hilphy, A.R.S., Niamah, A.K. and Al-Temimi, A.B.

Table 5. Chemical properties of rice milk during storage

\begin{tabular}{ccccc}
\hline \multirow{2}{*}{$\begin{array}{c}\text { Storage } \\
\text { (month) }\end{array}$} & \multicolumn{4}{c}{ Chemical compositions } \\
\cline { 2 - 5 } & Protein (\%) & Carbohydrate (\%) & Lipid (\%) & Anthocyanin (mg/L) \\
\hline 1 & $1.46 \pm 0.06$ & $6.22 \pm 0.20$ & $1.25 \pm 0.04$ & $2.17 \pm 0.08$ \\
2 & $1.47 \pm 0.05$ & $6.22 \pm 0.87$ & $1.26 \pm 0.02$ & $2.04 \pm 0.37$ \\
3 & $1.46 \pm 0.03$ & $6.55 \pm 0.42$ & $1.27 \pm 0.13$ & $1.66 \pm 0.08$ \\
4 & $1.46 \pm 0.02$ & $6.22 \pm 0.05$ & $1.26 \pm 0.01$ & $1.21 \pm 0.29$ \\
\hline
\end{tabular}

Values were expressed as mean $\pm \mathrm{SD}$ 
(2012). Effect of ultrasonic treatment on buffalo milk homogenization and numbers of bacteria. International Journal of Food Science and Nutrition Engineering, 2(6), 113-118. https:// doi.org/10.5923/j.food.20120206.03

AOAC. (2005). Official Methods of Analysis. 15 ${ }^{\text {th }}$ ed., Washington D.C., USA: AOAC.

Arunkumar, D., Avinash, N.G., Rao, H. and Robin, K.B. (2015). Estimation of calcium, potassium and sodium contents in commonly. Pelagia Research Library Der Chemica Sinica, 6(4), 100-103.

Baladhiya, C.S., Bhadania, A.G. and Mehta, B.M. (2018). Process optimization and shelf-life studies of thermally processed bottle gourd halwa. International Journal of Chemical Studies, 6(4), 1696-1700.

Banyavongsa, A., Linh, T.T.T., Tai, N.V. and Thuy, N.M. (2019). Response surface optimization of enzymatic hydrolysis of purple rice (cultivated in Soc Trang, Vietnam) using amylases and formulation of healthy rice milk. International Journal of Engineering Science Technology and Research, 6(10), 17-28.

Brodziak, A., Król, J., Litwińczuk, Z., Zaborska, A. and Czernecki, T. (2017). Effect of storage time under home refrigeration conditions on the quality of opened drinking milk. Original Scientific Paper, 67 (4), 283-296. https://doi.org/10.15567/ mljekarstvo.2017.0406

Bylund, G. (Ed.) (2003). Dairy processing handbook, p. 331-352. Switzerland: Tetra Pak.

Codex Alimentarius International Food Standards. (2011). Codex Standard for Milk and Milk Products - CODEX STAN-243-2003. Geneva, Rome: FAO.

Codina-Torrella, I., Guamis, B., Ferragut, V., Trujillo, A.J. (2017). The potential application of ultra-high pressure homogenization in the Physico-chemical stabilization of tiger nuts' milk beverage. Innovative Food Science and Emerging Technologies, 40, 4251. https://doi.org/10.1016/j.ifset.2016.06.023

Dinh, T.T.N., Blanton, J.R., Brooks, J.C., Miller, M.F. and Thompson, L.D. (2008). A simplified method for cholesterol determination in meat and meat products. Journal of Food Composition and Analysis, 21(4), 306-314. https://doi.org/10.1016/ j.jfca.2008.02.001

Fitrotin, U., Utami, T., Hastuti, P. and Santoso, U. (2015). Antioxidant properties of fermented sesame milk using lactobacillus Plantarum Dad 13. International Research Journal of Biological Sciences, 4(6), 56-61.

Furtado, P., Figueiredo, P., Chaves das Neves, H. and
Pina, F. (1993). Photochemical and thermal degradation of anthocyanidins. Journal of Photochemistry and Photobiology A: Chemistry, 73 (2), 113-118. https://doi.org/10.1016/1010-6030(93) 80191-B

Gaillard, S., Leguérinel, I., Savy, N. and Mafart, P. (2005). Quantifying the combined effects of the heating time, the temperature and the recovery medium $\mathrm{pH}$ on the regrowth lag time of Bacillus cereus spores after heat treatment. International Journal of Microbiology, 105(1), 53-58. https:// doi.org/10.1016/j.ijfoodmicro.2005.04.009

Holdsworth, S.D. (1985). Optimisation of thermal processing - A review. Journal of Food Engineering, 4(2), 89-116. https://doi.org/10.1016/0260-8774(85) 90014-7

Hu, C., Zawistowski, J., Ling, W. and Kitts, D.D. (2003). Black Rice (Oryza sativa L. indica) Pigmented Fraction Suppresses both Reactive Oxygen Species and Nitric Oxide in Chemical and Biological Model Systems. Journal of Agricultural and Food Chemistry, 51(18), 5271-5277. https:// doi.org/10.1021/jf034466n

Ikya, J.K., Gernah, D.I., Ojobo, H.E. and Oni, O.K. (2013). Effect of cooking temperature on some quality characteristics of soy milk. Advance Journal of Food Science and Technology, 5(5), 543-546. https://doi.org/10.19026/ajfst.5.3123

Jay, T.M. (Ed.) (2008). Milk, Fermentation, and Fermented and Nonfermented Dairy Products. In Modern Food Microbiology, p. 149-173. Boston, Massachusets, USA: Springer. https:// doi.org/10.1007/0-387-23413-6_7

Lomer, M.C.E., Parkes, G.C. and Sanderson, J.D. (2008). Review article: Lactose intolerance in clinical practice - Myths and realities. Alimentary Pharmacology and Therapeutics, 27(2), 93-103. https://doi.org/10.1111/j.1365-2036.2007.03557.x

Massoud, R., Fadaei, V. and Khosravi-Darani K. (2014). The effect of homogenization pressure and stages on the amounts of Lactic and Acetic acids of probiotic yoghurt. Applied Food Biotechnology, 2, 25-29.

McCseady, R.M. (1971). Determination of starch and dextrin in methods of Food Analysis. 2nd ed. London, UK: Academic Press.

Omer, R.H. and Eltinay, A.H. (2009). Changes in the chemical composition of camel's raw milk during storage. Pakistan Journal of Nutrition, 8(5), 607610. https://doi.org/10.3923/pjn.2009.607.610

Onweluzo, J.C. and Nwakalor, C. (2009). Development and evaluation of vegetable milk from Treculia Africana (Decne) seeds. Pakistan Journal of 
Nutrition, 8(3), 233-238. https://doi.org/10.3923/ pjn.2009.233.238

Padma, M., Jagannadarao, P.V.K., Edukondalu, L., Ravibabu, G. and Aparna, K. (2018). PhysicoChemical Analysis of Milk Prepared from Broken Rice. International Journal of Current Microbiology and Applied Sciences, 7(2), 426-428. https:// doi.org/10.20546/ijcmas.2018.702.054

Parrish, D.B. and Bauernfeind, J.C. (1977). Determination of vitamin a in foods - a review. Critical Reviews in Food Science and Nutrition, 9 (4), 375-394. https:// doi.org/10.1080/10408397709527240

Savage, G.P., Dutta, P.C. and Rodriguez-Estrada, M.T. (2002). Cholesterol oxides: Their occurrence and methods to prevent their generation in foods. Asia Pacific Journal of Clinical Nutrition, 11(1), 72-75. https://doi.org/10.1046/j.1440-6047.2002.00270.x

Sfakianakis, P. and Tzia, C. (2014). Conventional and Innovative Processing of Milk for Yogurt Manufacture; Development of Texture and Flavor: A Review. Foods 3(1), 176-193. https:// doi.org/10.3390/foods3010176

Shaker, R.R., Jumah, R.Y. and Jdayil, B.A. (2000). Rheological properties of plain yoghurt during the coagulation process: Impact of fat content and preheat treatment of milk. Journal of Food Engineering, 44(3), 175-180. https:// doi.org/10.1016/S0260-8774(00)00022-4

Shannon, R. and Rodriguez, J.M. (2014). Total arsenic in rice milk. Food Addict. Contam. Part B Surveill 7 (1), 54-56. https:// doi.org/10.1080/19393210.2013.842941

Shimakawa, Y., Matsubara, S., Yuki, N., Ikeda, M. and Ishikawa, F. (2003). Evaluation of Bifidobacterium breve strain Yakult-fermented soymilk as a probiotic food. International Journal of Food Microbiology, 81(2), 131-136. https://doi.org/10.1016/S0168-1605 (02)00224-6

Sivamaruthi, B.S., Pengkumsri, N., Saelee, M., Kesika, P., Sirilun, S., Peerajan, S. and Chaiyasut, C. (2016). Impact of physical treatments on stability and radical scavenging capacity of anthocyanidins. International Journal of Pharmacy and Pharmaceutical Sciences, 8(1), 162-167.

Thomson, J. and Manore, M. (2017). Nutrition an Applied Approach. $5^{\text {th }}$ ed. New York: Pearson.

Thuy, N.M., Dinh, D.C. and Tuyen, N.T.M. (2015). Application of Principal Component Analysis, Logistic Regression and Preference Map as sensory assessment tools for rice-based milk products. Journal of Can Tho University, 37, 11-20
Weemaes, C. (1997). In-pack thermal processing of foods. Belgium: Laboratory of Food Technology, Leuven University.

Yang, M. and Li, L. (2010). Physicochemical, textural and sensory characteristics of probiotic soy yoghurt prepared from germinated soybean. Food Technology and Biotechnology, 48(4), 490-496.

Zvaigzne, G., Karklina, D., Seglina, D. and Krasnova, I. (2009). Antioxidants in various citrus fruit juices. Chemine Technologija, 3, 56-61. 